\title{
Functional diversification of the dehydrin gene family in apple and its contribution to cold acclimation during dormancy
}

\author{
Vítor da Silveira Falavigna ${ }^{a}$, Yohanna Evelyn Miotto $^{b}$, Diogo Denardi Porto ${ }^{b, \dagger}$, Rafael Anzanelloc, $^{c, \$}$ \\ Henrique Pessoa dos Santos ${ }^{c}$, Flávio Bello Fialho ${ }^{c}$, Márcia Margis-Pinheiroa, Giancarlo Pasqualia and \\ Luís Fernando Revers ${ }^{\text {b,* }}$ \\ ${ }^{a}$ Graduate Program in Cell and Molecular Biology, Centro de Biotecnologia, Universidade Federal do Rio Grande do Sul, Porto Alegre, Brazil \\ bLaboratory of Plant Molecular Genetics, Centro Nacional de Pesquisa de Uva e Vinho, Empresa Brasileira de Pesquisa Agropecuária, Bento \\ Gonçalves, Brazil \\ 'Laboratory of Plant Physiology, Centro Nacional de Pesquisa de Uva e Vinho, Empresa Brasileira de Pesquisa Agropecuária, Bento Gonçalves, Brazil
}

\section{Correspondence \\ *Corresponding author, \\ e-mail: luis.revers@embrapa.br}

Received 2 December 2014; revised 6 March 2015

doi:10.1111/ppl.12338
Dehydrins (DHN) are proteins involved in plant adaptive responses to abiotic stresses, mainly dehydration. Several studies in perennial crops have linked bud dormancy progression, a process characterized by the inability to initiate growth from meristems under favorable conditions, with $D H N$ gene expression. However, an in-depth characterization of DHNs during bud dormancy progression is still missing. An extensive in silico characterization of the apple $D H N$ gene family was performed. Additionally, we used five different experiments that generated samples with different dormancy status, including genotypes with contrasting dormancy traits, to analyze how $D H N$ genes are being regulated during bud dormancy progression in apple by real-time quantitative polymerase chain reaction (RT-qPCR). Duplication events took place in the diversification of apple DHN family. Additionally, MdDHN genes presented tissue- and bud dormant-specific expression patterns. Our results indicate that $M d D H N$ genes are highly divergent in function, with overlapping levels, and that their expressions are fine-tuned by the environment during the dormancy process in apple.

\section{Introduction}

Dormancy in plants has been defined as the growth inability of meristems under favorable conditions (Rohde and Bhalerao 2007). Some perennial trees from temperate climates, such as apple (Malus $\times$ domestica Borkh.), display all three stages of bud dormancy progression: paradormancy, endodormancy and ecodormancy (Faust et al. 1997). In paradormancy, bud growth is inhibited due to signals produced in distal parts of the plant. Endodormancy, whose signal constraint to growth is within each bud, is triggered by low temperatures (LT)

†Present address: Centro de Pesquisa Agropecuária Trópico Semiárido, Empresa Brasileira de Pesquisa Agropecuária, Petrolina, PE 56302-970, Brazil.

¥Present address: Fundação Estadual de Pesquisa Agropecuária, Veranópolis, RS, 95330-000, Brazil.

Abbreviations - ARC5, accumulation and replication of chloroplast 5; CBF, C-repeat binding factor/DREB1; CH, chilling hours; $C R$, chilling requirement; DHN, dehydrin; LEA, late embryogenesis abundant; LT, low temperature; MBP, maximum budbreak percentage; $\mathrm{MDH}$, malate dehydrogenase; RACE, rapid amplification of CDNA ends; RT-qPCR, real-time quantitative polymerase chain reaction; TMp1, type 1 membrane protein-like; WD40, transcription factor WD40-like repeat domain; WGD, whole-genome duplication. 
and short days during autumn and winter (Horvath 2009). In order to overcome endodormancy, plants require a prolonged LT exposure to fulfill genotype-specific chilling requirements (CR) in order to promote the transition to the ecodormant state (Rohde and Bhalerao 2007). In ecodormancy, growth is temporarily inhibited by unfavorable environmental conditions, which is restored when plants are able to resume growth (Horvath 2009).

Dehydrins (DHNs) are a class of polypeptides that belong to group II of late embryogenesis abundant (LEA) proteins and are characterized by the presence of three characteristic motifs ( $\mathrm{K}$-, S- and Y-segments). These motifs are involved in responses to changes in water availability, mainly caused by abiotic stresses. Although many possible functions were reported for DHNs, their precise mechanisms of action remain unknown (reviewed in Rorat 2006, Hanin et al. 2011, Graether and Boddington 2014).

It has been suggested that the reduction of free water content in apple dormant buds coincides with DHN protein accumulation during winter (Faust et al. 1997). Indeed, several reports identified seasonal accumulation patterns of DHNs during winter in perennial plants (Wisniewski et al. 1996, Welling et al. 2004, Yamane et al. 2006, Yakovlev et al. 2008, Garcia-Bañuelos et al. 2009). In an attempt to compare low and high CR for apple cultivars, our group has recently reported a seasonal transcript accumulation pattern for $M d D H N 2$, MdDHN4 and MdDHN6 in dormant buds (Falavigna et al. 2014). These cultivars displayed elevated steady-state mRNA levels during winter in comparison to samples harvested in spring and summer. However, the apple cultivar with low CR showed an early decline of transcript levels in the end of winter compared to high CR cultivars, prior to growth resumption. Additionally, nine apple DHNs (MdDHN1-9) were characterized according to their transcription levels in different organs and under drought, LT and abscisic acid treatments, but their relationship with the bud dormancy process was not assessed (Liang et al. 2012).

In the present work, we investigate the expression of $M d D H N$ s within the context of bud dormancy progression and in selected growth developmental stages. The expression of all MdDHN genes was analyzed by real-time polymerase chain reaction (RT-qPCR) using samples representing dormancy, and from flowering to fruit ripening stages, including seeds. These samples provided an important resource to analyze how gene expression is being regulated during dormancy in apple. We identified five $M d D H N$ s regulated during the dormancy process, likely through the CBF (C-repeat binding
factor/DREB1) pathway, which may contribute to the bud tolerance to cold during dormancy.

\section{Materials and methods}

\section{Sampling strategy and controlled LT treatments}

Plant material was obtained from three apple orchards located in the cities of Vacaria, RS (-28.513777, -50.881465 and $972 \mathrm{~m}$ altitude), Caçador, SC $(-26.836971,-50.975246$ and $935 \mathrm{~m}$ altitude) and Papanduva, SC $(-26.434870,-50.106103$ and $788 \mathrm{~m}$ altitude), in Southern Brazil. All apple trees were in adult stage and underwent standard orchard management practices.

The experimental orchard in Vacaria consisted of three blocks with 10 'Gala Baigent' apple trees (3-yearold) each. The Gala Baigent trees were grafted on Marubakaido rootstocks with M.9 as interstock. Six apple developmental stages were partitioned in different tissues and organs resulting in 13 samples. The sample stages were defined according to the Fleckinger scale (EPPO 1984): closed terminal buds (A stage); buds at initial bursting (C stage); flower buds and young leaves (E2 stage); whole set-fruits approximately $10 \mathrm{~mm}$ in diameter and leaves (I stage); mature leaves and unripe fruits approximately $40 \mathrm{~mm}$ in diameter which were divided into pulp, seed and peel (J stage). Additionally, we sampled mature fruits approximately $70 \mathrm{~mm}$ in diameter partitioning them into pulp, seed and peel (named M). Samples were immediately frozen in liquid nitrogen in the field and stored at $-80^{\circ} \mathrm{C}$. Sampling dates and images of the developmental stages selected are presented in Table S1, Supporting Information.

The orchard in Caçador consisted of 7-year-old 'Fuji Standard' plants grafted on M.7 rootstocks. Three biological replicates consisted of pooled samples from four trees each. Forty closed terminal buds from each plant were harvested at eight time points from January 2009 to February 2010. Samples were immediately frozen in liquid nitrogen in the field and stored at $-80^{\circ} \mathrm{C}$ until use. Sampling dates and chilling hours $(\mathrm{CH}$, number of hours below $7.2^{\circ} \mathrm{C}$ ) accumulated by these samples are presented in Table S2.

Samples from Papanduva were taken from three blocks per cultivar (Castel Gala and Royal Gala), each block containing 20 plants. The selection of these genotypes was based on the contrasting CR of 'Royal Gala' $(600 \mathrm{CH})$ in relation to its natural bud sport 'Castel Gala' $(300 \mathrm{CH})$. The new cultivar has a precocious cycle usually starting growth a month earlier, being otherwise identical to the original cultivar (Denardi and Seccon 2005, Anzanello et al. 2014a). 'Castel Gala' plants were grafted on M.9 
rootstocks in 2006. 'Royal Gala' plants were grafted on Marubakaido rootstocks with M.9 as interstock in 2003. Sampled twigs ( $20 \mathrm{~cm}$ long) were disinfected with ethanol $70 \%$ for $45-60 \mathrm{~s}$ and sodium hypochlorite $2.5 \%$ for $20 \mathrm{~m}$, rinsed, air-dried and wrapped in black plastic bags. Treatments were performed by placing the bags inside growth chambers in the dark with the terminal bud upwards. Maximum budbreak percentages (MBP) of 40 twigs per treatment were determined as described by Anzanello et al. (2014b). Briefly, twigs were cut at the basis and fixed in floral foam inside a growth chamber under forcing conditions $\left(25 \pm 1.5^{\circ} \mathrm{C}, 12 \mathrm{~h}\right.$ photoperiod and $70 \%$ relative humidity). MBP was calculated by the total number of terminal buds showing green tips divided by the total number of viable terminal buds after 56 days in the growth chamber. These procedures were repeated on all twigs subjected to controlled temperature conditions (Fig. 6 and Figs S4 and S5). On April 5, 2011, a total of 420 twigs were sampled from each cultivar without $\mathrm{CH}$ exposure before that date. Twigs were exposed to a daily cycle of $12 \mathrm{~h}$ at $3^{\circ} \mathrm{C}$ and $12 \mathrm{~h}$ at $15^{\circ} \mathrm{C}$ until they reached $0,24,48,96,336$ and $600 \mathrm{CH}$ for 'Royal Gala' or 0, 24, 48, 96, 240 and $408 \mathrm{CH}$ for 'Castel Gala'. At each point, MBP was determined and 30 additional closed terminal buds were frozen in liquid nitrogen and stored at $-80^{\circ} \mathrm{C}$. Additionally, two experiments under controlled LT conditions, performed with samples of the same experimental area, are described in Figs S4 and S5.

\section{In silico analysis of $M d D H N$ genes and deduced amino acid sequences}

To identify predicted gene models coding for DHNs in the apple genome version 1.0 (http://rosaceae.org/; Velasco et al. 2010), we performed BLASTP searches using the conserved K-segment as query (Altschul et al. 1990). All hits obtained had their sequences annotated by comparison with the $\mathrm{NCBI}$ non-redundant protein database using the BLAST2GO software with an E-value cutoff of $1 \mathrm{e}^{-6}$ (Conesa et al. 2005).

Deduced amino acid sequences of $12 \mathrm{MdDHNs}$ were used for searching conserved domains using MEME Suite v.4.9.0 (Bailey and Elkan 1994). Default parameters were used, except motif distribution among sequences was set to any number of repetitions, maximum number of motifs was set to 5 and maximum motif width was defined between 6 and 16 amino acids.

Full-length protein sequences of DHNs from Arabidopsis thaliana, Hordeum vulgare, Glycine max, Malus $\times$ domestica, Oryza sativa, Populus trichocarpa, Prunus mume and Vitis vinifera were aligned using ClustalW (Higgins et al. 1994). References and accession numbers of all sequences used are presented in Table S3. The phylogenetic tree was inferred using MRBAYES version 3.1.2 (Huelsenbeck and Ronquist 2001) employing the mixed amino acid substitution model in default settings. Four million generations were run, sampled every 100 generations and the first $25 \%$ trees were discarded as burn-in. The remaining ones were summarized in a consensus tree, which was visualized and edited using FiGTREE v.1.4 (http://tree.bio.ed.ac.uk/software /figtree/).

Collinear block analysis was performed by comparing the whole-genome protein sequences from apple against themselves and against those from $P$. mume using BLASTP ( $E$-value $<1 \mathrm{e}^{-10}$, top five matches). The results and gene positions were used as inputs to determine the collinear blocks using MCSCANX (Wang et al. 2012).

\section{Nucleic acid extraction and CDNA synthesis}

Approximately $200 \mathrm{mg}$ of frozen plant material was used for nucleic acid isolation. DNA was purified from mature leaves of 'Gala Baigent' trees according to Lodhi et al. (1994) and Lefort and Douglas (1999) modified protocols adapted to $2 \mathrm{ml}$ tubes. Total RNA of each sampled material was isolated as described in Falavigna et al. (2014) and DNase-treated using TURBO DNA-free Kit (Ambion, Austin, TX). Complementary DNA was synthesized using the GeneAmp RNA PCR Core Kit (Applied Biosystems, Foster City, CA) according to manufacturer's instructions. DNA-free RNA samples from mature seeds were also employed in $5^{\prime}$ and $3^{\prime}$ rapid amplification of cDNA ends (RACE) for MdDHN10 and MdDHN11 cDNA synthesis using the SMARTer RACE cDNA Amplification Kit (Clontech, Mountain View, CA) according to the manufacturer's protocol. RACE products were sequenced at ACTGene Ltd. (Porto Alegre, Brazil) using an automatic ABI-PRISM 3100 Genetic Analyzer and associated chemistry (Applied Biosystems).

\section{Real-time quantitative polymerase chain reaction}

Gene-specific primers were designed using the PRIMER3 v0.4.0 software (Table S4; Rozen and Skaletsky 2000). RT-qPCR was performed as described in Falavigna et al. (2014). Biological samples $(n=3)$ were analyzed in four technical replicates. PCR efficiency was calculated using LINREGPCR v.2012.0 (Ruijter et al. 2009). Mean relative gene expression was calculated by the Pfaffl method (2001). Reference genes used for organ and tissue samples were $M D H$ (malate dehydrogenase), TMp1 (type 1 membrane protein-like) and WD40 (transcription factor WD40-like repeat domain), whereas ARC5 (accumulation and replication of chloroplast 5), $\mathrm{MDH}$ and $\mathrm{WD} 40$ 
were employed as reference genes for closed terminal buds as described by Perini et al. (2014).

\section{Results}

\section{Identification and classification of $M d D H N$ gene family}

In order to identify genes coding for MdDHNs, a BLASTP search was performed in the apple genome (http://rosaceae.org/) using the consensus sequence of the K-segment, a motif ubiquitously present in the DHN family of proteins in plants (Rorat 2006). We identified 16 predicted gene models and their deduced peptide sequences were annotated using the BLAST2GO software. The gene sequence represented by the accession number MDP0000156140 was excluded based on low similarity to LEA proteins. Multiple alignments of the remaining 15 sequences revealed that MDP0000126135 and MDP0000770493 were identical and four gene models seemed to be artifacts of the genome assembly. MDP0000595270 and MDP0000595271 were predicted in the genome contig MDC011430.191, whereas MDP0000868044 and MDP0000868045 were derived from contig MDC016760.214. The gene model MDP0000595271 exhibited a predicted start codon within the intron of MDP0000868045 and the remaining sequences were identical. Moreover, MDP0000595270 and MDP0000868044 were identical in their $3^{\prime}$ portion. These two results suggested that one of these two contigs was misplaced in the genome assembly. To test this hypothesis, we performed a PCR spanning a common region of both contigs. The analysis showed that only the amplicon from the contig MDC016760.214 was amplified. Sequencing of the amplicon confirmed the identity of the fragment, supporting the idea that only contig MDC016760.214 is properly positioned within apple chromosome 2 . We, therefore, excluded MDP0000126135, MDP0000156140, MDP0000595270 and MDP0000595271 from further analyses.

Our genome-wide survey identified nine genes (MdDHN1-9) previously identified by Liang et al. (2012), and three additional family members, named MdDHN10-12 (Fig. 1). MdDHN10 and MdDHN11 were amplified by RACE and sequenced (GenBank KF578380 and KF578381). The obtained sequence for

\begin{tabular}{|c|c|c|c|c|c|}
\hline Gene Name & $\begin{array}{c}\text { Genome } \\
\text { Accession Code }\end{array}$ & $\begin{array}{c}\text { GenBank } \\
\text { Accession Code }\end{array}$ & $\begin{array}{l}\text { Chromosomal } \\
\text { Localization }\end{array}$ & Type & Motif Distribution \\
\hline$M d D H N 1$ & $\begin{array}{l}\text { MDP0000868045/ } \\
\text { MDP0000595271 }\end{array}$ & JQ649456 & $\begin{array}{c}\text { chr2:12477545..12478867/ } \\
\text { chr2:8259119..8259842 }\end{array}$ & $\mathrm{Y}_{2} \mathrm{SK}_{3}$ & a $\square \square \square=\square \square$ \\
\hline MdDHN2 & MDP0000698024 & JQ649457 & chr2:12484455..12485624 & $\mathrm{Y}_{2} \mathrm{SK}_{3}$ & घm $\square \square \square \square \square \square$ \\
\hline MdDHN3 & MDP0000689622 & JQ649458 & chr2:12500269...12500520 & $\mathrm{K}_{4}$ & 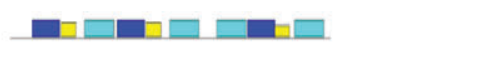 \\
\hline MdDHN4 & MDP0000360414 & JQ649459 & chr2:12500767..12501879 & $\mathrm{Y}_{2} \mathrm{SK}_{3}$ & $m \square \square \square \square \square \square \square$ \\
\hline MdDHN5 & MDP0000862169 & JQ649460 & chr2:12503902..12504672 & $\mathrm{YK}_{4}$ & $\square \square=\square \square \square \square \square \square \square$ \\
\hline MdDHN6 & MDP0000265874 & JQ649461 & chr2:12701912..12702484 & $\mathrm{YK}_{3}$ & $\square \square \square \square$ \\
\hline MdDHN7 & MDP0000196703 & JQ649462 & chr2:12736190..12736886 & $\mathrm{K}_{3}$ & $\square \square \square \square$ \\
\hline MdDHN8 & MDP0000529003 & JQ649463 & chr12:20761988..20764699 & $\mathrm{SK}_{3}$ & $\square \square$ \\
\hline MdDHN9 & $\begin{array}{l}\text { MDP0000770493/ } \\
\text { MDP0000126135 }\end{array}$ & JQ649464 & $\begin{array}{l}\text { chr15:6960886..6962054/ } \\
\text { chr15:6977891..6979059 }\end{array}$ & $\mathrm{SK}_{3}$ & $\square \square \square \square$ \\
\hline MdDHN10 & $\begin{array}{l}\text { MDP0000868044/ } \\
\text { MDP0000595270 }\end{array}$ & KF578380 & $\begin{array}{c}\text { chr2:12470746..12472298/ } \\
\text { chr2:8255278..8257253 }\end{array}$ & $\mathrm{Y}_{3} \mathrm{SK}_{3}$ & $\square \square \square \square \square$ \\
\hline MdDHN11 & MDP0000629961 & KF578381 & chr10:10172519..10178352 & $\mathrm{Y}_{3} \mathrm{SK}_{2}$ & $m_{n}=\square \square \square$ \\
\hline MdDHN12 & MDP0000178973 & - & chr9:21206400..21207388 & $\mathrm{K}_{6}$ & $=\square \square \square \square \square$ \\
\hline
\end{tabular}

Fig. 1. Identification and classification of apple DHN genes. Names were attributed following Liang et al. (2012). Genome and GenBank accession codes are provided by the 'Malus domestica Genome' (http://rosaceae.org/) and NCBI (http://www.ncbi.nlm.nih.gov/) databases, respectively. Chromosomal localization and DHN classification are shown. Schematic view of the conserved motifs between deduced protein sequences of MdDHNs performed by MEME (Bailey and Elkan 1994) is shown. Each colored box represents a conserved motif: cyan blue represents K-segments; red represents S-segments; pink represents Y-segments; dark blue and yellow represent putative novel motifs. The height of the motif box is proportional to -log ( $P$ value), with the maximum height composed by a $P$ value of $1 \mathrm{e}^{-10}$. Gray lines represent non-conserved sequences. See Fig. S2 for individual motif details. GenBank accession codes for MdDHN1-9 were provided by Liang et al. (2012). 
MdDHN10 was identical to the model predicted in the apple genome. However, alignments for MdDHN11 revealed that, out of four predicted exons in the genome, only the second and the third are truly transcribed (Fig. S1). No transcript for MdDHN12 was detected in our RACE attempts (see section 'MdDHN transcript levels in apple tissues and organs').

Predicted amino acid sequences for all $12 \mathrm{MdDHNs}$ were screened for conserved domains using the MEME software. The analysis identified five significantly conserved motifs (Fig. 1), including those classified as K-segment (Fig. S2A), S-segment (Fig. S2C) and Y-segment (Fig. S2D). Two putative DHN conserved motifs (Fig. S2B, E) were additionally found and considered as novel because no matches with known domains in Pfam (Punta et al. 2012), PROSITE (Sigrist et al. 2013) and SMART (Letunic et al. 2012) databases were found. As a result, we assigned the $12 \mathrm{MdDHNs}$ into four of five DHN subclasses (Hanin et al. 2011). The subgroups $\mathrm{Y}_{n} \mathrm{SK}_{\mathrm{n}}$ and $\mathrm{K}_{\mathrm{n}}$ were the most represented with five and three members, respectively. Subgroups $\mathrm{SK}_{\mathrm{n}}$ and $\mathrm{YK}_{\mathrm{n}}$ displayed two members each, whereas no MdDHN was assigned to the $K_{n} S$ subclass (Fig. 1).

\section{Evolutionary relationships of $M d D H N s$}

Deduced peptide sequences from all MdDHNs and those from seven other plant species (Table S3) whose DHN family members have been previously described were used in a phylogenetic analysis employing MRBAYES (Fig. 2). The resulting tree topology indicated that the majority of the proteins could be grouped into six major clusters of orthologous and paralogous proteins (A-F), with apple members distributed into four of them (groups A, C, D and F). Groups A and B were mainly composed of $Y_{n} S K_{n}$ subclass, group $E$ with $K_{n}$ and $K_{n} S$ subclasses and group $\mathrm{F}$ with $\mathrm{SK}_{\mathrm{n}}$ subclass. Interestingly, groups $\mathrm{C}$ and $\mathrm{D}$ comprised all MdDHNs from chromosome 2 together with their counterparts in P. mume and G. max. Additionally, we identified putative orthologs between apple and $P$. mume, such as MdDHN11/PmLEA20 and MdDHN12/PmLEA19. The remaining MdDHNs grouped as paralogs. Only At3g50970, HvDHN5, PtDHN10 and $\mathrm{VvDHN} 1$ did not group with other members in the tree.

In order to infer the evolutionary history of the DHN genes in the Rosaceae family, a synteny study was performed between the genomes of apple and P. mume using the MCSCANX software. This algorithm is able

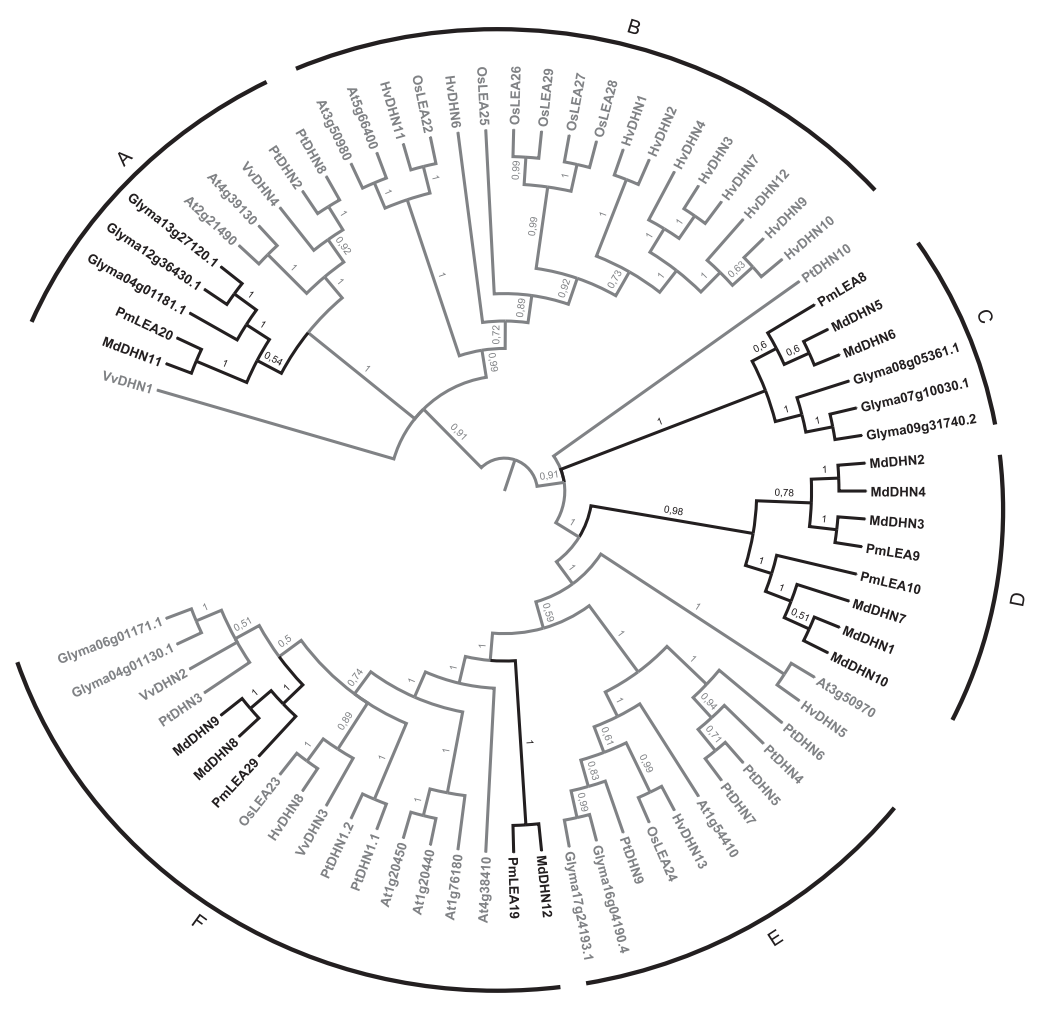

Fig. 2. Phylogenetic relationships for full-length amino acid sequences of DHNs from Arabidopsis thaliana, Hordeum vulgare, Glycine max, Malus $\times$ domestica, Oryza sativa, Populus trichocarpa, Prunus mume and Vitis vinifera. The six groups (A-F) of orthologous and paralogous proteins identified are shown. The tree was inferred using MrBAYES v.3.1.2 (Huelsenbeck and Ronquist 2001). Nodal support is given by a posteriori probability values shown next to the corresponding nodes (when $>0.50$ ). All accession codes used in the phylogenetic analysis are depicted in Table $\mathbf{S 3 .}$ 


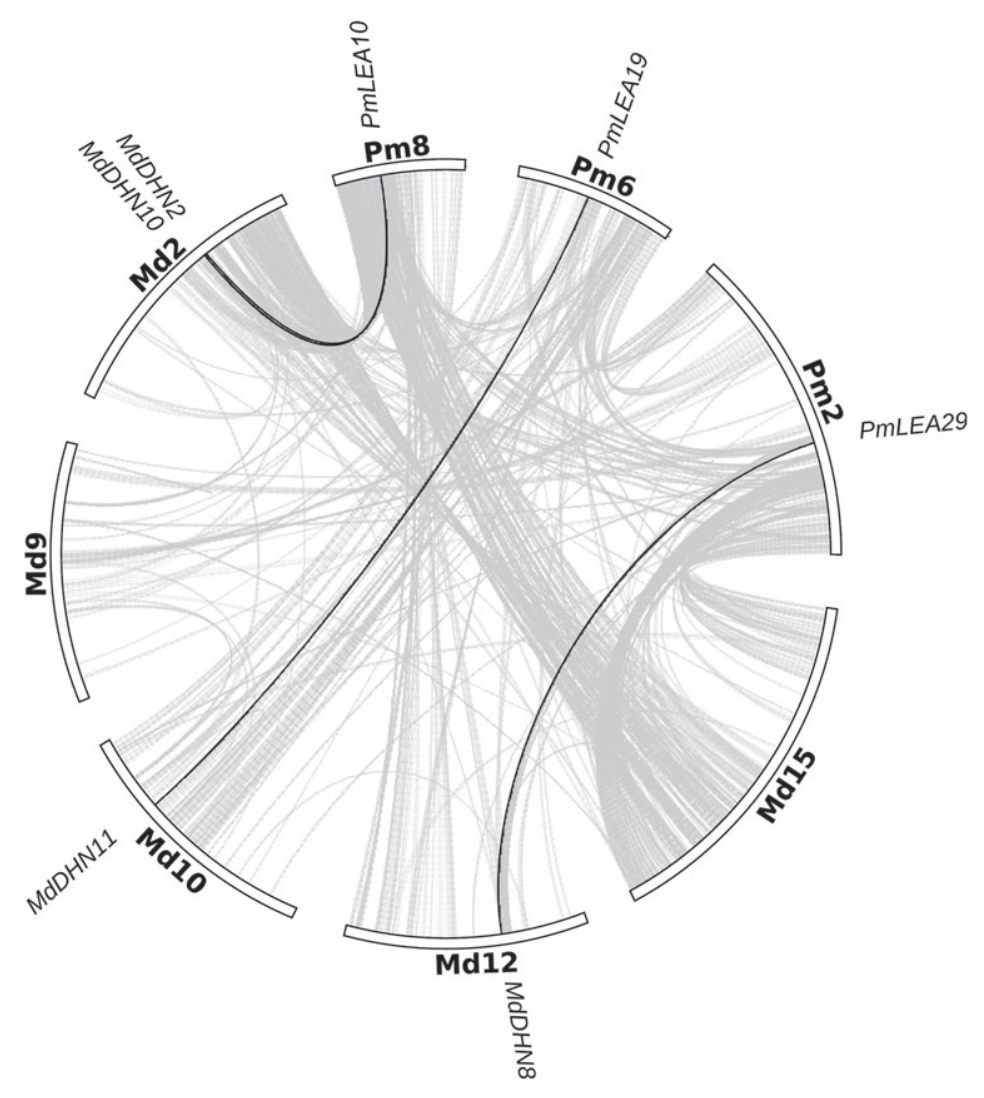

Fig. 3. Synteny analysis of $D H N$ genes from apple and Prunus mume. Chromosomes containing apple (Md2, 9, 10, 12 and 15) and Prunus mume (Pm2, 6 and 8) DHN genes are depicted. Lines connecting two chromosomal regions indicate collinearity relationships with (black) or without (gray) the involvement of $D H N$ genes.

to scan genomes recognizing putative homologous chromosomal regions using genes as anchors (Wang et al. 2012). This analysis identified many collinear regions between the genomes (gray lines in Fig. 3), with four collinear blocks containing DHNs (black lines in Fig. 3). Of these, two were between chromosome 8 from $P$. mume and chromosome 2 from apple (PmLEA10/MdDHN2 and PmLEA10/MdDHN10), one was between chromosome 6 from $P$. mume and chromosome 10 from apple (PmLEA19/MdDHN11) and one was found between chromosome 2 from $P$. mume and chromosome 12 from apple (PmLEA29/MdDHN8). In summary, these results indicate the presence of conserved genomic regions containing DHNs of apple and $P$. mume, suggesting that genome duplication events likely played important roles in the expansion of this gene family in Rosaceae species.

\section{MdDHN transcript levels in different tissues and organs}

The transcript accumulation of MdDHNs was investigated by RT-qPCR in 13 different organs and tissues. Tissue/organ sampling dates and developmental stages are presented in Table S1. Four different patterns of expression were identified (Fig. 4). MdDHN1 and MdDHN11 were expressed mainly in seeds of unripe and ripe fruits, with very low relative levels of transcripts in other organs or tissues analyzed. While MdDHN1 exhibited more than 120-fold higher transcript accumulation in mature seeds compared to closed terminal buds, strikingly, MdDHN11 expression was about 6000 -fold higher in mature seeds relative to closed terminal buds. MdDHN2, MdDHN3 and MdDHN4 were expressed mainly in closed terminal buds, with some expression in pulp and peel of mature fruits. Additionally, MdDHN2 showed low level of expression in mature seeds in comparison to closed terminal buds. MdDHN5 and MdDHN6 presented similar transcript accumulation in closed terminal buds and mature seeds. MdDHN7, MdDHN8, MdDHN9 and MdDHN10 were detected in nearly all tissues and organs analyzed. While MdDHN7 presented higher transcript amounts in young leaves and seeds, MdDHN8 and MdDHN9 showed higher transcript accumulation in pulp and peel 


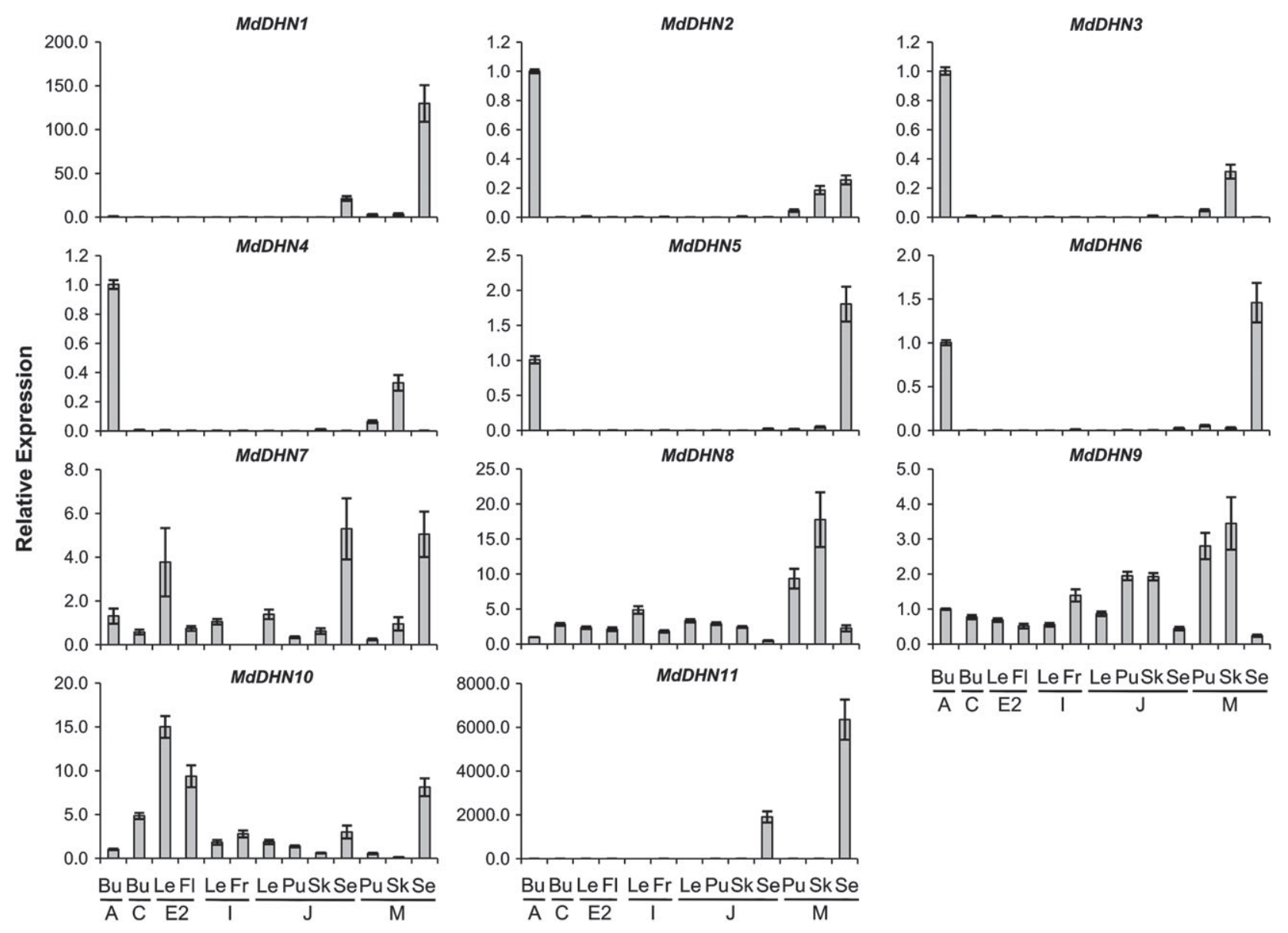

Fig. 4. Mean relative expression levels in 13 different apple tissues and organs. Stages A, C, E2, I and J were sampled according to the Fleckinger phenological scale (EPPO 1984). 'M' stands for mature fruits. Sampling dates and images of the developmental stages considered are presented in Table S1. Bu, bud; Le, leaf; Fl, flower; Fr, fruit; Pu, fruit pulp; Sk, fruit peel and Se, seed. Relative transcript levels in closed terminal buds (Bu/A) were set to 1 . Standard error bars are shown.

of mature fruits and MdDHN10 was detected mainly in young flowers and young leaves. Finally, MdDHN12 transcripts were not detected in any of the tissues or organs analyzed under our conditions. We nevertheless confirmed the presence of the MdDHN12 sequence in the apple genome by PCR amplification from genomic DNA (Fig. S3) and by sequencing of the amplicon (data not shown).

\section{Transcript accumulation of $M d D H N$ genes through the annual growth cycle}

We analyzed the transcript accumulation for MdDHN111 by RT-qPCR in closed terminal buds sampled from the high CR cultivar Fuji Standard during a complete growing cycle from January 2009 to February 2010 (Fig. 5). We carefully monitored chilling exposure (Table S2), growth cessation and the onset of growth resumption (50\% of buds in green tip stage) as markers for dormancy establishment and completion. Because budbreak occurred on September 15, 2009, which corresponds to the end of winter in Southern Brazil (September 21 equinox), we therefore considered samples from May 27 (growth cessation) to September 9, 2009 (near growth resumption) as representing the complete bud dormancy progression.

The $M d D H N$ gene family displayed a clear seasonal pattern of transcript accumulation (Fig. 5). The expression timing of MdDHN1, MdDHN9 and MdDHN10 coincides most closely with the growth resumption, with a gradual transcript decline during spring and summer. MdDHN2, MdDHN3, MdDHN4, MdDHN5, MdDHN6, MdDHN8 and MdDHN11 showed a noticeable peak of transcript accumulation during winter and their expressions drastically decreased near budbreak, maintaining low levels through spring and summer. MdDHN2 and MdDHN4 showed the highest levels of transcriptional induction, and MdDHN3, MdDHN4, 

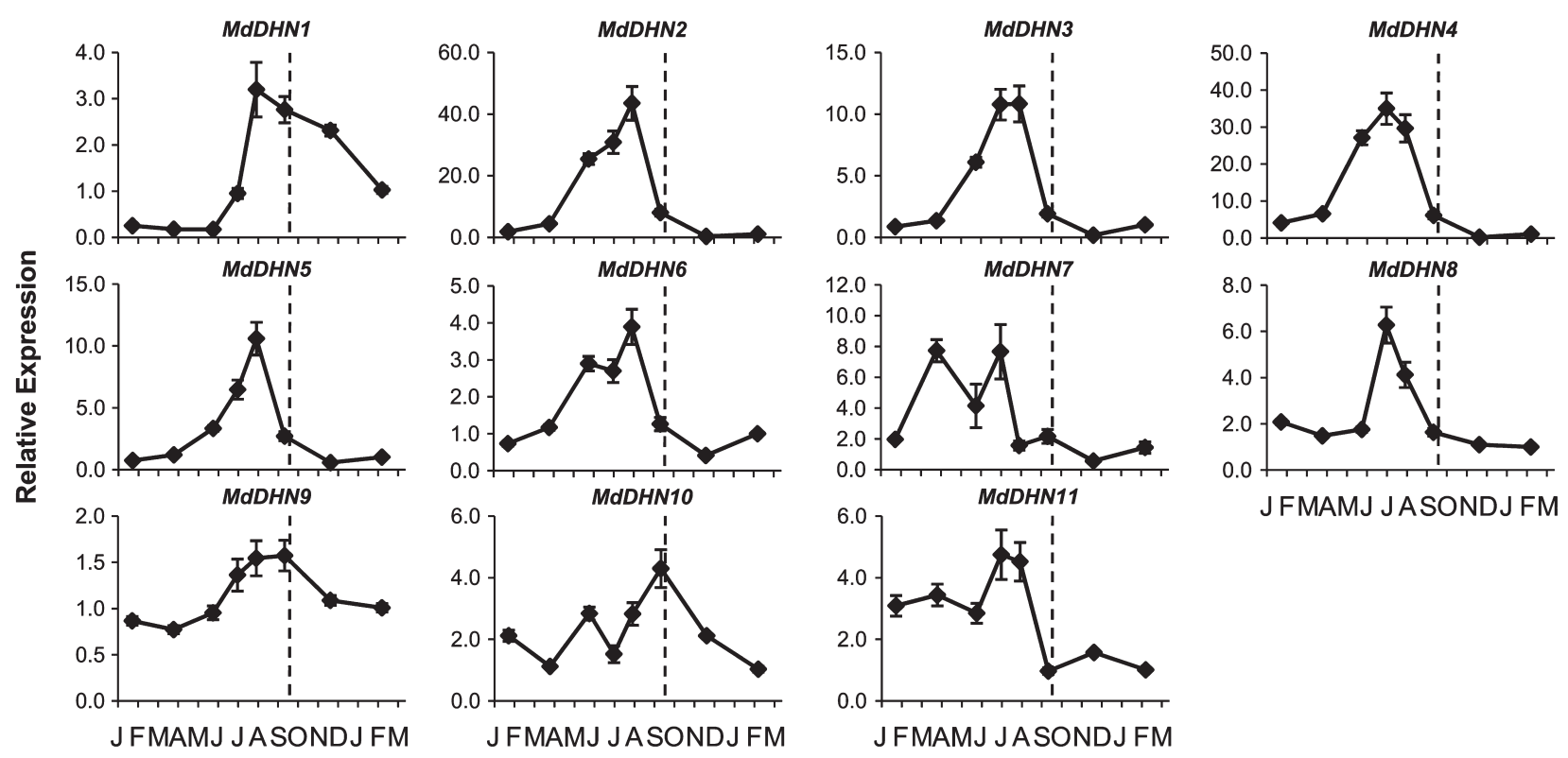

Fig. 5. Kinetics of the relative transcript levels for MdDHN1-11 during 2009/2010. RT-qPCRs were performed with RNA samples isolated from closed terminal buds harvested from 'Fuji Standard' trees grown in Caçador (SC). Dashed lines correspond to budbreak date (50\% of buds in green tip stage), which occurred on September 15, 2009 (end of winter). Months are represented by their initial letters on the x-axis. Relative transcript levels in February 2010 were set to 1 . Standard error bars are shown. Graphics for MdDHN2, MdDHN4 and MdDHN6 genes were reproduced from Falavigna et al. (2014), with permission of the publisher.

MdDHN8 and MdDHN11 presented their expression peaks occurring concomitantly with winter solstice (June 21). Finally, MdDHN7 was the only member that presented an oscillatory pattern of expression in the beginning of autumn and winter combined with the same fast reduction to low levels of expression prior to growth resumption.

\section{Gene expression of $M d D H N s$ in samples with contrasting dormancy status}

We performed three experiments to produce samples with contrasting MBP. Two experiments used contrasting CR cultivars with similar genetic backgrounds, 'Castel Gala' and 'Royal Gala'. The first experiment was performed in 2009, and the MBP analysis revealed that 'Castel Gala' (86.4\%) showed a much higher percentage of budburst than 'Royal Gala' (7.7\%), confirming the expected behavior of 'Castel Gala' (Fig. S4A). After $504 \mathrm{~h}$ of exposure to LT6 $\left(6^{\circ} \mathrm{C}\right)$, both cultivars displayed similar MBP, which persisted until the end of the treatments. In the second experiment, both cultivars had the endodormancy process induced and released by treating sampled twigs with a daily cycle of $12 \mathrm{~h}$ at $3^{\circ} \mathrm{C}$ and $12 \mathrm{~h}$ at $15^{\circ} \mathrm{C}$ (Fig. 6A, B). After $96 \mathrm{CH}$, 'Royal Gala' decreased the MBP from 60.4 to $14.1 \%$. The MBP almost doubled after 336 $\mathrm{CH}$ and, at the end of the treatment, $46.6 \%$ of budbreak was obtained. 'Castel Gala' twigs showed a decrease in MBP from 67.2 to $33.5 \%$ after $48 \mathrm{CH}$. After $240 \mathrm{CH}$, the growth competence almost returned to field samples levels $(61 \%)$. At the end of the treatment, $83.5 \%$ of budbreak was obtained.

Despite the evident difference in MBP (Fig. 6A, B and Fig. $\mathrm{S} 4 \mathrm{~A})$, similar transcriptional responses were identified between cultivars. MdDHN2-6 showed a continuous increase in gene expression during the treatments, with MdDHN2, MdDHN3 and MdDHN5 presenting the highest transcript amounts (Fig. 6C, D). Despite the relative baseline expression, MdDHN7-10 presented a peak of transcripts during 24 and $48 \mathrm{CH}$ and then restored similar levels to the ones observed in field samples in the rest of the experiment. Finally, MdDHN1 and MdDHN11 displayed a slight increase in transcript levels in the first part of the treatment, which persisted until the end of the analysis. In 2009 samples (Fig. S4B), $168 \mathrm{~h}$ of LT6 exposure increased gene expression of all MdDHNs in both cultivars, except for MdDHN7. After $840 \mathrm{~h}$ of LT6, three distinct responses were observed: $M d D H N 1$ and MdDHN11 were further induced; MdDHN2, MdDHN5, MdDHN6 MdDHN8 and MdDHN9 maintained the same level of transcript accumulation observed at $168 \mathrm{~h}$ and MdDHN3, MdDHN4 and MdDHN10 showed a decline in transcript levels. MdDHN7 showed similar levels of 
(a)

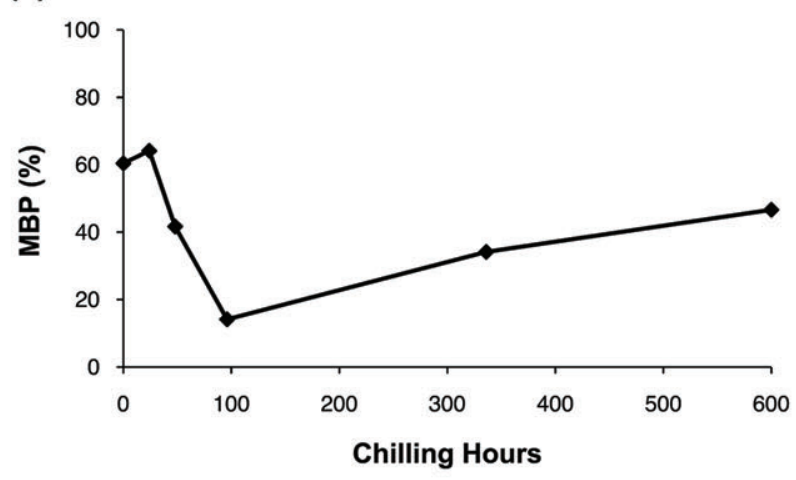

(b)

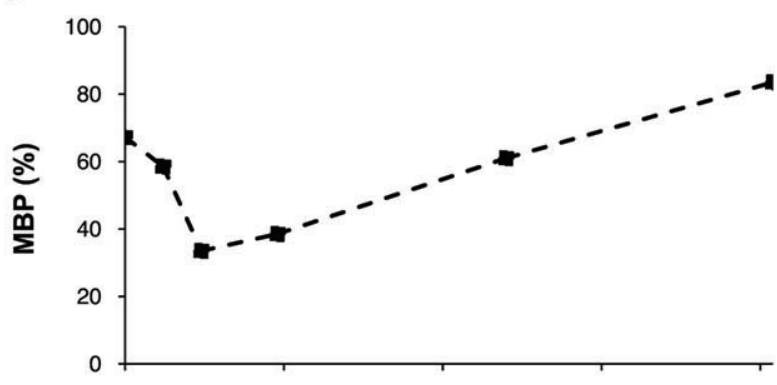

Chilling Hours

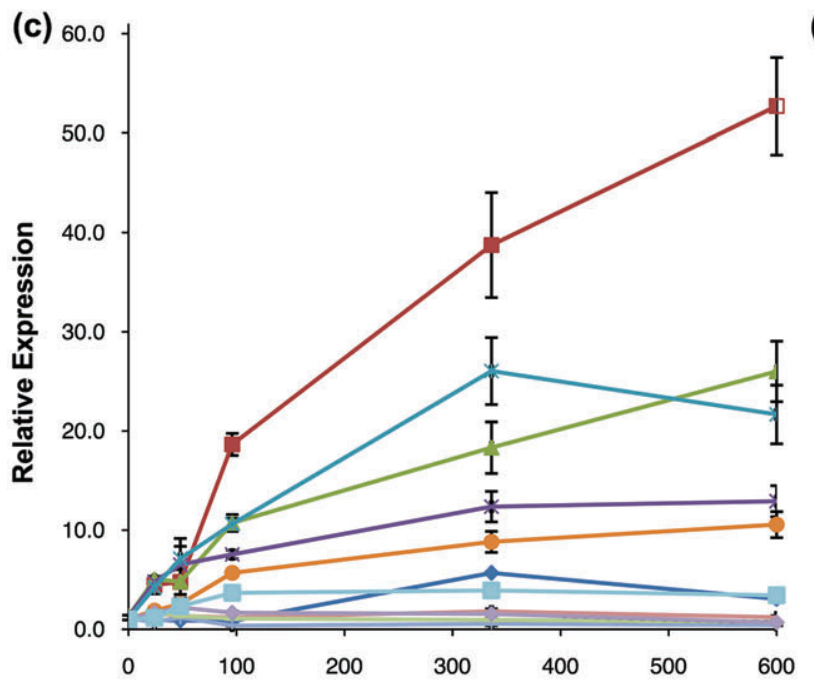

(d)

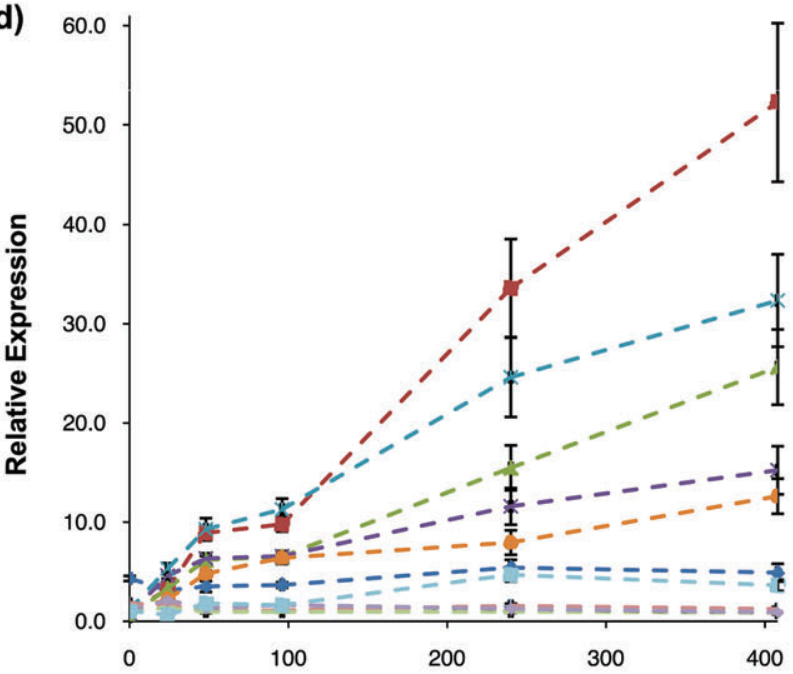

$\multimap$ MdDHN1 $\rightarrow-$ MdDHN2 $\rightarrow$ MdDHN3 $\multimap$ MdDHN4 $\multimap$ MdDHN5 $\rightarrow$ MdDHN6

$\longrightarrow$ MdDHN7 $\longrightarrow$ MdDHN8 $\longrightarrow$ MdDHN9 $\multimap$ MdDHN10 - MdDHN11

Fig. 6. Endodormancy analysis and relative expression levels of MdDHN1-11 genes. MBP analysis of 'Royal Gala' (A) or 'Castel Gala' (B) twigs after treatments $\left(3^{\circ} \mathrm{C} / 15^{\circ} \mathrm{C}\right.$ for $\left.12 / 12 \mathrm{~h}\right)$ in a growth chamber. Mean relative expression levels were performed by RT-qPCR of RNAs isolated from closed terminal buds of 'Royal Gala' (C) or 'Castel Gala' (D) twigs. Solid lines, 'Royal Gala'; dashed lines, 'Castel Gala'. Relative transcript levels in the field sample $(\mathrm{O} \mathrm{CH})$ were set to 1 . Standard error bars are shown in the gene expression graphs.

transcript accumulation during cold treatments for 'Royal Gala' and a slight decrease in 'Castel Gala' samples.

The last experiment explored the effects of cold $\left(3^{\circ} \mathrm{C}, \mathrm{LT} 3\right)$ and growth permissive $\left(25^{\circ} \mathrm{C}\right)$ temperatures on $M d D H N$ transcript accumulation profiles during endodormancy of 'Royal Gala'. After 168 and $438 \mathrm{~h}$ under LT3, MBP initially at $6.6 \%$, increased to 16.6 and $61.6 \%$, respectively (Fig. S5A). However, exposure to $25^{\circ} \mathrm{C}$ diminished MBP to $9.3 \%$. Re-exposure to LT3 recovered MBP to some extent $(14.4 \%)$. The twigs were maintained for $168 \mathrm{~h}$ under cold because this treatment was able to induce $M d D H N$ s expression (Fig. S4B). Two distinct patterns of transcript accumulation were identified (Fig. S5B). MdDHN1, MdDHN7, $M d D H N 8, M d D H N 10$ and MdDHN11 were clearly induced by growth permissive temperature. Re-exposure to LT3 further induced their expressions, except for $M d D H N 7$, which showed a slight repression. Conversely, MdDHN2, MdDHN3, MdDHN4, MdDHN5, MdDHN6 and MdDHN9 showed a drastic decrease in transcript levels after acclimation at $25^{\circ} \mathrm{C}$, with re-exposure to LT3 being able to restore transcript levels. In control samples, no substantial alteration of transcript levels was observed, except for MdDHN7 and MdDHN9 that were down-regulated.

\section{Discussion}

DHNs are proteins known to play important roles in plant adaptive responses to abiotic stresses, mainly dehydration (Rorat 2006). Several studies linking $D H N$ expression to bud dormancy (Welling et al. 
2004, Yamane et al. 2006, Yakovlev et al. 2008, Garcia-Bañuelos et al. 2009, Porto et al. 2015), including a previous work from our group (Falavigna et al. 2014), have been reported. Recently, nine gene models coding for DHNs in apple were identified but not using bud dormancy as subjected (Liang et al. 2012). Therefore, the identification of $M d D H N$ genes being expressed during bud dormancy in our previous work (Falavigna et al. 2014) and the recent description of the gene family in apple (Liang et al. 2012) prompted us to better characterize how $M d D H N$ genes are regulated during bud dormancy progression.

The identification of gene families in a genome search can lead to divergent results according to the employed methodology, and it was observed when comparing our data to the results reported by Liang et al. (2012). In their analyses, an HMM (hidden Markov models)-based (Finn et al. 2011) search was employed to identify putative DHNs in the apple genome retrieving 12 candidates for the family. In our screening, the conserved DHN $\mathrm{K}$-segment was used as query in BLASTP searches against the same apple genome. Our analysis rendered 16 matches, comprising the 12 putative $M d D H N$ s previously described and four novel candidates (Fig. 1). Following the identification of $12 \mathrm{MdDHN}$ members, Liang et al. (2012) screened apple EST (expressed sequence tag) databases to verify whether these genes were expressed. Sequences without any matches were discarded, yielding nine genes (MdDHN1-9) that were used in their further analysis. In our manual approach to remove artifacts from the candidate list, we were able to precisely select predicted gene models, revealing three novel apple DHNs (MdDHN10-12; Fig. 1). Furthermore, our analysis showed that MdDHN10 and MdDHN11 are expressed (Figs 4-6).

We performed a motif-based analysis to search conserved motifs previously described for DHN proteins (Rorat 2006), using the MEME software (Bailey and Elkan 1994). Our classification for MdDHN1 -9 matched with the one described by Liang et al. (2012), with the exception of MdDHN1 and MdDHN4. Because a statistical significance was found for two Y-segments in these sequences, both putative proteins were therefore classified as $\mathrm{Y}_{2} \mathrm{SK}_{3}$ instead of $\mathrm{YSK}_{3}$ (Fig. 1). Additionally, all MdDHNs were assigned into four of five subclasses reported for DHNs. No MdDHN belonging to the $K_{n} S$ subclass was found. DHNs from this specific subclass were proposed to exhibit hydroxyl and peroxyl radical-scavenging activity under cellular dehydration stresses (Hara et al. 2003, Hara et al. 2004). This might suggest that other genes or even MdDHNs assigned to other subclasses may be responsible for this kind of reactive oxygen species detoxification in apple. In addition to the known conserved DHN domains, two novel DHN motifs were identified using sequences from Arabidopsis, barley and poplar (Liu et al. 2012b). In addition, two other highly conserved motifs were found in DHNs from maritime pine (Perdiguero et al. 2012). Finally, our analysis identified two distinct new motifs exploring apple DHNs (Fig. 1; Fig. S2B, E). These data suggest that uncharacterized domains of $\mathrm{DHN}$ proteins may exist and further investigation needs to be conducted to unveil their functional roles.

The number of DHN genes in apple (12) suggests that duplication events may have happened. Analyzing a $35 \mathrm{~kb}$ region of the apple chromosome 2, six $M d D H N$ s are arranged in tandem, suggesting that this kind of gene duplication event also could be held accountable for the amount of DHN genes in apple. Additionally, as suggested by Velasco et al. (2010), the genome of the domesticated apple has undergone a recent whole-genome duplication (WGD) event that certainly contributed to the higher number of $D H N$ genes in apple in comparison to its Rosaceae counterpart $P$. mume, which did not undergo a recent WGD (Zhang et al. 2012). In grapevine, four DHN genes were identified and no evidence for duplication events in this family was found (Yang et al. 2012). However, gene family expansion by means of duplication events was a recurrent feature for the $D H N$ family in other species. In $P$. mume and rice, the DHN family is composed of six and eight members, respectively, with both species displaying genes arranged as tandem repeats (Wang et al. 2007, Du et al. 2013). In other species, besides tandem rearrangements, segmental duplication may have equally contributed to the expansion of DHN family, which is composed of 10 members in Arabidopsis (Hundertmark and Hincha 2008), 13 in barley (Battaglia et al. 2008), 11 in poplar (Liu et al. 2012b) and 10 in soybean (Yamasaki et al. 2013).

The construction of phylogenetic trees showed MdDHN members present into four of the six clusters identified. All MdDHNs that mapped to chromosome 2 clustered in groups C and D (Fig. 2). Three PmDHNs, which are disposed as tandem repeats in the genome (Du et al. 2013), are also present in these groups. The synteny analysis revealed that PmLEA10 is one of a series of genes that show collinear relationships with two regions of apple chromosome 2, one region containing MdDHN2 and other containing MdDHN10 (Fig. 3). Additionally, PmLEA29 and MdDHN8 concomitantly clustered in the same branch of the phylogenetic tree and mapped to the same collinear region. Taken together, these results suggest that, at least for the DHN gene family, duplication events happened after the Rosaceae family diversification from Prunus and Malus ancestors, 
with another round of gene duplication events occurring only in the Malus genus (Figs 2 and 3).

In order to quantify the transcript accumulation of MdDHN1-11 in different apple tissues and organs, RT-qPCR was performed (Fig. 4). However, our results differed from those reported by Liang et al. (2012), who performed semi-quantitative RT-PCR in five organs: flower, fruit, leaf, root and seed. Only MdDHN7, MdDHN8 and MdDHN9 shared common expression patterns comparing both studies. These different results may derive from at least three possible reasons. First, we identified five genes mainly expressed in closed terminal buds, which were not analyzed by Liang et al. (2012). Moreover, because $D H N$ expression is highly regulated by temperature and water availability, the differences between results may be due to environmental factors. Finally, RT-qPCR is a much more sensitive technique than semi-quantitative RT-PCR and permits an accurate quantification (Gachon et al. 2004).

Interestingly, 7 of 12 genes (approximately $64 \%$ ) of this family were mostly expressed in dormant organs, i.e. seeds and closed terminal buds (Fig. 4). This finding is in agreement with transcript accumulation patterns described previously for the LEA gene family, which is known to be up-regulated during seed maturation and desiccation, phenomena related to seed dormancy in Arabidopsis (Rorat 2006, Holdsworth et al. 2008, Angelovici et al. 2010). Furthermore, a recent report identified common transcriptional pathways during dormancy release of buds and seeds in peach, including a LEA-like family member (Leida et al. 2012). Therefore, we suggest that some adaptive pathways analogous to seed dormancy may also be present in the bud dormancy process. Finally, the marked expression of MdDHN11, reaching 6000-fold higher levels in mature seeds relative to closed terminal buds, suggest that this gene has an important role in seed tolerance to desiccation (Fig. 4).

Comparative genomics aims to track characteristic features of orthologs in multiple genomes (Thornton and DeSalle 2000). Therefore, the identification of orthologous and paralogous sequences along with functional information may be used as a tool to predict gene function (Zhang 2003). In fact, some interesting relationships may be drawn by the comparison of the phylogenetic results with the RT-qPCR data (Figs 2 and 4). All genes that clustered in groups $\mathrm{A}$ and $\mathrm{C}$ were mostly expressed in seeds (Hundertmark and Hincha 2008, Liu et al. 2012b, Yang et al. 2012, Yamasaki et al. 2013, this work). PmDHNs were mainly expressed in flowers, although gene expression in seed was not analyzed (Du et al. 2013). We, therefore, propose that $D H N s$ from groups $\mathrm{A}$ and $\mathrm{C}$ are mostly seed-expressed genes. MdDHN1, MdDHN7, MdDHN10 and PmLEA10 formed a branch in group D. Interestingly, PmLEA10 was expressed in all five P. mume organs analyzed (Du et al. 2013) and a very similar expression pattern was also found for MdDHN7 and MdDHN10 (Fig. 4). Finally, MdDHN8 and MdDHN9, which exhibited a transcript accumulation pattern throughout many tissues and organs of apple, formed a branch with PmLEA29 in group F. Accordingly, PmLEA29 also presented a wide pattern of transcript accumulation in Prunus (Du et al. 2013). In conclusion, our phylogenetic analysis strongly agrees with our transcript accumulation data, reinforcing the importance of the combination of these analyses in the prediction of $D H N$ gene function.

The gene expression of $M d D H N s$ was analyzed through an annual cycle of 'Fuji Standard' closed terminal buds. Transcripts of MdDHN1, MdDHN9 and MdDHN10 accumulated after winter, in a similar trend to the results reported for pear and sessile oak (Liu et al. 2012a, Ueno et al. 2013). Moreover, Tompa et al. (2006) characterized water and ion binding of AtDHNs and showed that these proteins can bind large amounts of water and solute ions. In this sense, the DHN competence to retain water could be one possible explanation to our findings, given that water supply is a necessary attribute during normal plant growth. On the other hand, MdDHN2, MdDHN3, MdDHN4, MdDHN5, MdDHN6, MdDHN8 and MdDHN11 showed a seasonal transcriptional profile during winter allied with a remarkable repression near budbreak (Fig. 5). Similar seasonal patterns of $D H N$ transcript accumulation was already found in field-harvested samples of birch and Norway spruce (Welling et al. 2004, Yakovlev et al. 2008), bark tissues of eight woody species and during bud dormancy in P. mume (Wisniewski et al. 1996, Yamane et al. 2006). DHN accumulation, even under the metabolically less active endodormant state, might be partially explained by the reduction of water availability observed in buds during winter (de Fay et al. 2000, Améglio et al. 2002, Rinne et al. 2011).

In an attempt to characterize the seasonal MdDHN expression previously identified in closed terminal buds (Fig. 5), three experiments using controlled temperatures were carried out to produce contrasting MBP samples. We gathered data that confirmed the contrasting $C R$ between Castel Gala and Royal Gala cultivars (Fig. 6A, B and Fig. S4A; Denardi and Seccon 2005, Anzanello et al. 2014a); and the reversion of the chilling effect over endodormancy after exposure to growth permissive temperatures (Fig. S5A; Richardson et al. 1974, Erez et al. 1979, Young 1992).

In the first experiment, all $M d D H N$ genes presented increased steady-state mRNA levels after exposure to LT6, suggesting that cold affects gene regulation of the 
whole $M d D H N$ family, with the exception of MdDHN7 (Fig. S4B). However, studies analyzing gene expression of the DHN family in apple and grapevine seedlings under cold treatment found that only a few members were induced by this condition (Liang et al. 2012, Yang et al. 2012), suggesting that closed terminal buds impose a different regulation mechanism over $M d D H N$ expression under cold (Fig. S4). Interestingly, when analyzing the influence of growth permissive temperatures during endodormancy, two patterns of gene expression were observed (Fig. S5). Prolonged exposure to $25^{\circ} \mathrm{C}$ decreased the transcript accumulation levels of MdDHN2-6. Furthermore, these genes restored their expression levels after re-exposure to cold, although no significant alterations in the MBP were measured. These profiles closely agree with the models proposed for almond, birch and peach DHNs (Welling and Palva 2008, Barros et al. 2012, Artlip et al. 2013). In these models, some members of the CBF family of transcription factors are involved in cold acclimation after endodormancy induction, and seasonally regulate the expression of DHNs. In addition, Arora et al. (1997) induced cold acclimation in blueberry floral buds followed by a dormancy neutral treatment that caused deacclimation. These authors observed an increased level of DHN proteins during acclimation followed by a reduction after deacclimation. Their results suggest that DHN changes are more closely related to cold hardiness rather than with dormancy. In agreement to Arora et al. (1997), our findings suggest that $M d D H N 2-6$ are environmentally regulated, probably mediated by $\mathrm{CBFs}$, and our treatment likely triggered a deacclimation process in these bud samples.

Finally, our last experiment attempted to simulate the winter season in Southern Brazil, as we used a daily cycle of $12 \mathrm{~h}$ at $3^{\circ} \mathrm{C}$ and $12 \mathrm{~h}$ at $15^{\circ} \mathrm{C}$ to induce and release dormancy (Fig. 6). Once again, MdDHN2-6 were differentially regulated in comparison to the other $M d D H N$ s. Interestingly, buds kept accumulating MdDHN2-6 transcripts while dormant, given that we analyzed gene expression before forcing budburst. Considering that these five genes present at least one C-repeat/DRE cis element in their promoter regions (data not shown), one hypothesis could be that the transcriptional regulation of these five genes during bud dormancy likely occurs through the CBF pathway. This result agrees with the findings reported by Artlip et al. (2013), who stated that peach $C B F$ s are $L T$-inducible and directly regulate the expression of $P p D H N 1$, the promoter of which contains two C-repeat/DRE cis elements. Furthermore, ectopic expression of a peach $C B F$ in apple triggered dormancy induction by short days (Wisniewski et al. 2011). The same group further analyzed the expression of genes known to be associated with freezing tolerance and dormancy in these plants proposing a model where CBFs regulate the expression of apple dormancy-related genes while concomitantly induce cold-regulated genes, such as DHNs (Wisniewski et al. 2015). Within this context, MdDHN accumulation could be one of the mechanisms partially responsible for bud cold tolerance during winter. For instance, the ability of DHNs to shift their conformational status during changes in water availability, as also the ability to bind in partly dehydrated surfaces of other proteins (Tompa et al. 2006, Graether and Boddington 2014), could act protecting bud integrity. In summary, our results indicate that distinct MdDHNs play different functions in the cell, with overlapping levels, and that their expressions are fine-tuned by the environment during the dormancy process in apple.

\section{Author contributions}

V.S. F., Y. E. M. and D.D. P. performed all the sampling, RNA extraction and cDNA synthesis. V.S.F. also performed the RT-qPCR assay, the bioinformatic analysis, analyzed the data and drafted the manuscript. Y. E.M. and D.D. P. also carried out the RACE assays. R.A., H.P. S. and F. B. F. designed and executed the controlled temperature experiments. L. F. R., M. M. P. and G. P. contributed for the experimental design, discussion of the results and revision of the manuscript.

Acknowledgements - We thank Dr Paulo R.D. de Oliveira and Dr João C. Fioravanço (Embrapa Uva e Vinho), MSc Frederico Denardi and Dr Marcus V. Kvitschal (Empresa de Pesquisa Agropecuária do Estado de Santa Catarina) and Mr Décio Amorim for providing us with the access to apple orchards. We gratefully acknowledge our colleagues at Laboratory of Plant Molecular Genetics and Laboratory of Plant Physiology at Embrapa Uva e Vinho, especially to Ms Vanessa Buffon and Mr Daniel A. Souza for technical assistance. This work was supported by 'Financiadora de Estudos e Projetos' (FINEP, Brazil) (grant number 0107009700) and Embrapa (Brazil) (grant number 0207070070003). V. S. F. received a PhD scholarship from 'Coordenação de Aperfeiçoamento de Pessoal de Nível Superior' (Brazil), R. A. received a PhD scholarship from 'Conselho Nacional de Desenvolvimento Científico e Tecnológico' (CNPq, Brazil) and D. D. P. firstly received a postdoctoral scholarship from CNPq and lately from 'Fundação de Amparo à Pesquisa do Estado do Rio Grande do Sul' (Brazil). G. P. and M. P. M. are recipients of research fellowships from $\mathrm{CNPq}$ (grant numbers 311361/2009-9 and 306945/2009-6, respectively). The nucleotide sequences reported in this paper have been submitted to GenBank under the accession numbers KF578380 and KF578381. 


\section{References}

Altschul SF, Gish W, Miller W, Myers EW, Lipman DJ (1990) Basic local alignment search tool. J Mol Biol 215: 403-410

Améglio T, Bodet C, Lacointe A, Cochard H (2002) Winter embolism, mechanisms of xylem hydraulic conductivity recovery and springtime growth patterns in walnut and peach trees. Tree Physiol 22: 1211-1220

Angelovici R, Galili G, Fernie AR, Fait A (2010) Seed desiccation: a bridge between maturation and germination. Trends Plant Sci 15: 211-218

Anzanello R, Fialho FB, dos Santos HP, Bergamaschi H, Marodin GAB (2014a) Bud dormancy in apple trees after thermal fluctuations. Pesq Agropec Bras 49: 457-464

Anzanello R, Fialho FB, dos Santos HP, Bergamaschi H, Marodin GAB (2014b) Biological methods for assessment of budbreak in apple trees for modeling dormancy. Semina Ciênc Agrár 35: 1163-1176

Arora R, Rowland LJ, Panta GR (1997) Chill-responsive dehydrins in blueberry: are they associated with cold hardiness or dormancy transitions? Physiol Plant 101: $8-16$

Artlip TS, Wisniewski ME, Bassett CL, Norelli JL (2013) CBF gene expression in peach leaf and bark tissues is gated by a circadian clock. Tree Physiol 33: 866-877

Bailey TL, Elkan C (1994) Fitting a mixture model by expectation maximization to discover motifs in biopolymers. Proc Int Conf Intell Syst Mol Biol 2: 28-36

Barros PM, Gonçalves N, Saibo NJM, Oliveira MM (2012) Cold acclimation and floral development in almond bud break: insights into the regulatory pathways. J Exp Bot 63: 4585-4596

Battaglia M, Olvera-Carrillo Y, Garciarrubio A, Campos F, Covarrubias AA (2008) The enigmatic LEA proteins and other hydrophilins. Plant Physiol 148: 6-24

Conesa A, Götz S, García-Gómez JM, Terol J, Talón M, Robles M (2005) Blast2GO: a universal tool for annotation, visualization and analysis in functional genomics research. Bioinformatics 21: 3674-3676

de Fay E, Vacher V, Humbert F (2000) Water-related phenomena in winter buds and twigs of Picea abies $\mathrm{L}$. (Karst.) until bud-burst: a biological, histological and NMR study. Ann Bot 86: 1097-1107

Denardi F, Seccon JJ (2005) 'Castel Gala' - mutação da macieira 'Gala' com baixa necessidade de frio e maturação precoce. Agropec Catar 18: 78-82

Du D, Zhang Q, Cheng T, Pan H, Yang W, Sun L (2013) Genome-wide identification and analysis of late embryogenesis abundant (LEA) genes in Prunus mume. Mol Biol Rep 40: 1937-1946

EPPO (1984) EPPO crop growth stage keys - apple and pear. EPPO Bull 14: 291-294

Erez A, Couvillon GA, Hendershott CH (1979) The effect of cycle length on chilling negation by high temperatures in dormant peach leaf buds. J Am Soc Hortic Sci 104: 573-576

Falavigna VS, Porto DD, Buffon V, Margis-Pinheiro M, Pasquali G, Revers LF (2014) Differential transcriptional profiles of dormancy-related genes in apple buds. Plant Mol Biol Rep 32: 796-813

Faust M, Erez A, Rowland LJ, Wang SY, Norman HA (1997) Bud dormancy in perennial fruit trees: physiological basis for dormancy induction, maintenance and release. Hortscience 32: 623-629

Finn RD, Clements J, Eddy SR (2011) HMMER web server: interactive sequence similarity searching. Nucleic Acids Res 39: W29-W37

Gachon C, Mingam A, Charrier B (2004) Real-time PCR: what relevance to plant studies? J Exp Bot 55: 1445-1454

Garcia-Bañuelos ML, Gardea AA, Winzerling JJ, Moreno LV (2009) Characterization of a midwinter-expressed dehydrin (DHN) gene from apple trees (Malus domestica). Plant Mol Biol Rep 27: 476-487

Graether SP, Boddington KF (2014) Disorder and function: a review of the dehydrin protein family. Front Plant Sci 5: 576

Hanin M, Brini F, Ebel C, Toda Y, Takeda S, Masmoudi K (2011) Plant dehydrins and stress tolerance: Versatile proteins for complex mechanisms. Plant Signal Behav 6: 1503-1509

Hara M, Terashima S, Fukaya T, Kuboi T (2003) Enhancement of cold tolerance and inhibition of lipid peroxidation by citrus dehydrin in transgenic tobacco. Planta 217: 290-298

Hara M, Fujinaga M, Kuboi T (2004) Radical scavenging activity and oxidative modification of citrus dehydrin. Plant Physiol Biochem 42: 657-662

Higgins D, Thompson J, Gibson T, Thompson JD, Higgins DG, Gibson TJ (1994) CLUSTAL W: improving the sensitivity of progressive multiple sequence alignment through sequence weighting, position-specific gap penalties and weight matrix choice. Nucleic Acids Res 22: $4673-4680$

Holdsworth MJ, Bentsink L, Soppe WJJ (2008) Molecular networks regulating Arabidopsis seed maturation, after ripening, dormancy and germination. New Phytol 179: 33-54

Horvath DP (2009) Common mechanisms regulate flowering and dormancy. Plant Sci 177: 523-531

Huelsenbeck JP, Ronquist F (2001) MRBAYES: Bayesian inference of phylogeny. Bioinformatics 17: 754-755

Hundertmark M, Hincha DK (2008) LEA (late embryogenesis abundant) proteins and their encoding genes in Arabidopsis thaliana. BMC Genomics 9: 118

Lefort F, Douglas GC (1999) An efficient micro-method of DNA isolation from mature leaves of four hardwood tree species Acer, Fraxinus, Prunus and Quercus. Ann For Sci 56: $259-263$ 
Leida C, Conejero A, Arbona V, Gómez-Cadenas A, Llácer G, Badenes ML, Ríos G (2012) Chilling-dependent release of seed and bud dormancy in peach associates to common changes in gene expression. PLoS One 7: 1-9

Letunic I, Doerks T, Bork P (2012) SMART 7: recent updates to the protein domain annotation resource. Nucleic Acids Res 40: D302-D305

Liang D, Xia H, Wu S, Ma F (2012) Genome-wide identification and expression profiling of dehydrin gene family in Malus domestica. Mol Biol Rep 39: 10759-10768

Liu G, Li W, Zheng P, Xu T, Chen L, Liu D, Hussain S, Teng Y (2012a) Transcriptomic analysis of 'Suli' pear (Pyrus pyrifolia white pear group) buds during the dormancy by RNA-Seq. BMC Genomics 13: 700

Liu C, Li C, Ge S, Dong X, Li W, Zhu H, Wang B, Yang C (2012b) Genome-wide identification and characterization of a dehydrin gene family in poplar (Populus trichocarpa). Plant Mol Biol Rep 30: 848-859

Lodhi MA, Guang-Ning Y, Weeden NF, Reisch BI (1994) A simple and efficient method for DNA extraction from grapevine cultivars, Vitis species. Plant Mol Biol Rep 12: $6-13$

Perdiguero P, Barbero MC, Cervera MT, Soto A, Collada C (2012) Novel conserved segments are associated with differential expression patterns for Pinaceae dehydrins. Planta 236: 1863-1874

Perini P, Pasquali G, Margis-Pinheiro M, Oliveira PRD, Revers LF (2014) Reference genes for transcriptional analysis of flowering and fruit ripening stages in apple (Malus $\times$ domestica Borkh.). Mol Breeding 34: 829-842

Pfaffl MW (2001) A new mathematical model for relative quantification in real-time RT-PCR. Nucleic Acids Res 29: 2002-2007

Porto DD, Bruneau M, Perini P, Anzanello R, Renou J, dos Santos HP, Fialho FB, Revers LF (2015) Transcription profiling of the chilling requirement for budbreak in apples: a putative role for FLC-like genes. J. Exp. Bot. first published online March 5, doi:10.1093/jxb/erv061

Punta M, Coggill PC, Eberhardt RY, Mistry J, Tate J, Boursnell C, Pang N, Forslund K, Ceric G, Clements J, Heger A, Holm L, Sonnhammer ELL, Eddy SR, Bateman A, Finn RD (2012) The Pfam protein families database. Nucleic Acids Res 40: D290-D301

Richardson EA, Seeley SD, Walker DR (1974) A model for estimating the completion of rest for 'Redhaven' and 'Elberta' peach trees. Hortscience 9: 331-332

Rinne PLH, Welling A, Vahala J, Ripel L, Ruonala R, Kangasjärvi J, van der Schoot C (2011) Chilling of dormant buds hyperinduces FLOWERING LOCUS T and recruits GA-inducible 1,3- $\beta$-glucanases to reopen signal conduits and release dormancy in Populus. Plant Cell 23: $130-146$
Rohde A, Bhalerao RP (2007) Plant dormancy in the perennial context. Trends Plant Sci 12: 217-223

Rorat T (2006) Plant dehydrins - tissue location, structure and function. Cell Mol Biol Lett 11: 536-556

Rozen S, Skaletsky HJ (2000) Primer3 on the WWW for general users and for biologist programmers. In: Krawetz S, Misener S (eds) Bioinformatics Methods and Protocols: Methods in Molecular Biology. Humana Press, Totowa, pp 365-386

Ruijter JM, Ramakers C, Hoogaars WM, Karlen Y, Bakker O, van den Hoff MJ, Moorman AF (2009) Amplification efficiency: linking baseline and bias in the analysis of quantitative PCR data. Nucleic Acids Res 37: e45

Sigrist CJA, de Castro E, Cerutti L, Cuche BA, Hulo N, Bridge A, Bougueleret L, Xenarios I (2013) New and continuing developments at PROSITE. Nucleic Acids Res 41: D344-D347

Thornton JW, DeSalle R (2000) Gene family evolution and homology: genomics meets phylogenetics. Annu Rev Genomics Hum Genet 1: 41-73

Tompa P, Bánki P, Bokor M, Kamasa P, Kovács D, Lasanda G, Tompa K (2006) Protein-water and protein-buffer interactions in the aqueous solution of an intrinsically unstructured plant dehydrin: NMR intensity and DSC aspects. Biophys J 91: 2243-2249

Ueno S, Klopp C, Leplé JC, Derory J, Noirot C, Léger V, Prince E, Kremer A, Plomion C, Le Provost G (2013) Transcriptional profiling of bud dormancy induction and release in oak by next-generation sequencing. BMC Genomics 14: 236

Velasco R, Zharkikh A, Affourtit J, Dhingra A, Cestaro A, Kalyanaraman A, Fontana P, Bhatnagar SK, Troggio M, Pruss D, Salvil S, Pindo M, Baldi P, Castellettil S, Cavaiuolo M, Coppola G, Costa F, Cova V, Dal Ri A, Goremykin V, Komjanc M, Longhi S, Magnago P, Malacarne G, Malnoyl M, Micheletti D, Moretto M, Perazzolli M, Si-Ammour A, Vezzulli S, Zini E, Eldredge G, Fitzgerald LM, Gutin N, Lanchbury J, Macalma T, Mitchell JT, Reid J, Wardell B, Kodira C, Chen Z, Desany B, Niazi F, Palmer M, Koepke T, Jiwan D, Schaeffer S, Krishnan V, Wu C, Chu VT, King ST, Vick J, Tao Q, Mraz A, Stormo A, Stormo K, Bogden R, Ederle D, Stella A, Vecchietti A, Kater MM, Masiero S, Lasserre P, Lespinasse $\mathrm{Y}$, Allan AC, Bus V, Chagné D, Crowhurst RN, Gleave AP, Lavezzo E, Fawcett JA, Proost S, Rouzé P, Sterck L, Toppo S, Lazzari B, Hellens RP, Durel CE, Gutin A, Bumgarner RE, Gardiner SE, Skolnick M, Egholm M, Peer YV, Salamini F, Viola R (2010) The genome of the domesticated apple (Malus $\times$ domestica Borkh.). Nat Genet 42: 833-839

Wang X, Zhu H, Jin G, Liu H, Wu W, Zhu J (2007) Genome-scale identification and analysis of LEA genes in rice (Oryza sativa L.). Plant Sci 172: 414-420 
Wang Y, Tang H, DeBarry JD, Tan X, Li J, Wang X, Lee T, Jin H, Marler B, Guo H, Kissinger JC, Paterson AH (2012) MCScanX: a toolkit for detection and evolutionary analysis of gene synteny and collinearity. Nucleic Acids Res 40: e49

Welling A, Palva ET (2008) Involvement of CBF transcription factors in winter hardiness in birch. Plant Physiol 147: 1199-1211

Welling A, Rinne P, Viherä-Aarnio A, Kontunen-Soppela S, Heino P, Palva ET (2004) Photoperiod and temperature differentially regulate the expression of two dehydrin genes during overwintering of birch (Betula pubescens Ehrh.). J Exp Bot 55: 507-516

Wisniewski M, Close TJ, Artlip T, Arora R (1996) Seasonal patterns of dehydrins and 70-kDa heat-shock proteins in bark tissues of eight species of woody plants. Physiol Plant 96: 496-505

Wisniewski M, Norelli J, Bassett C, Artlip T, Macarisin D (2011) Ectopic expression of a novel peach (Prunus persica) $C B F$ transcription factor in apple (Malus $\times$ domestica) results in short-day induced dormancy and increased cold hardiness. Planta 233: 971-983

Wisniewski M, Artlip T, Norelli J (2015) Overexpression of a peach $C B F$ gene in apple: a model for understanding the integration of growth, dormancy, and cold hardiness in woody plants. Front Plant Sci 6: 85

Yakovlev IA, Asante DAK, Fossdal CG, Partanen J, Junttila O, Johnsen $\varnothing$ (2008) Dehydrins expression related to timing of bud burst in Norway spruce. Planta 228: 459-472

Yamane H, Kashiwa Y, Kakehi E, Yionemori K, Mori H, Hayashi K, Iwamoto K, Tao R, Kataoka I (2006) Differential expression of dehydrin in flower buds of two Japanese apricot cultivars requiring different chilling requirements for bud break. Tree Physiol 26: 1559-1563

Yamasaki Y, Koehler G, Blacklock BJ, Randall SK (2013) Dehydrin expression in soybean. Plant Physiol Biochem 70: $213-220$

Yang Y, He M, Zhu Z, Li S, Xu Y, Zhang C, Singer SD, Wang $Y$ (2012) Identification of the dehydrin gene family from grapevine species and analysis of their responsiveness to various forms of abiotic and biotic stress. BMC Plant Biol 12: 140
Young E (1992) Timing of high temperature influences chilling negation in dormant apple trees. J Am Soc Hortic Sci 117: 271-272

Zhang J (2003) Evolution by gene duplication: an update. Trends Ecol Evol 18: 292-298

Zhang Q, Chen W, Sun L, Zhao F, Huang B, Yang W, Tao Y, Wang J, Yuan Z, Fan G, Xing Z, Han C, Pan H, Zhong X, Shi W, Liang X, Du D, Sun F, Xu Z, Hao R, Lv T, Lv Y, Zheng Z, Sun M, Luo L, Cai M, Gao Y, Wang J, Yin Y, Xu X, Cheng T, Wang J (2012) The genome of Prunus mume. Nat Commun 3: 1318

\section{Supporting Information}

Additional Supporting Information may be found in the online version of this article:

Table S1. Sampling dates and developmental stages of the different tissues and organs harvested.

Table S2. Sampling dates, corresponding season and chilling hours accumulated by closed terminal buds harvested in 2009 and 2010.

Table S3. Accession codes of DHN genes used in the phylogenetic analysis.

Table S4. Primers employed in RT-qPCR studies.

Fig. S1. Sequence alignment between genomic and RACE sequences of MdDHN11.

Fig. S2. Significantly enriched motifs of $\mathrm{MdDHN}$ deduced proteins identified with the MEME software.

Fig. S3. PCR analysis of MdDHN12 in 'Gala Baigent' apple trees.

Fig. S4. Endodormancy analysis and relative expression levels of MdDHN1-11 genes in apple twigs exposed to cold.

Fig. S5. Endodormancy analysis and $M d D H N 1-11$ relative expression in 'Royal Gala' twigs exposed to cold and growth permissive temperatures. 